\title{
Social impacts with the end of the manual sugarcane harvest: a case study in Brazil
}

\begin{abstract}
Brazil is the largest producer of sugarcane in the world, the expansion of the sugarenergy sector has been redesigning the agrarian space in the regions of its cultivation, changing the relations of production, replacing crops, concentrating lands and modifying labor relations. The present article presents the results of the research carried out in the Ituiutaba Microregion in the western of Minas Gerais state, Brazil, which represents one of the most productive areas of the State where the replacement of manual harvest by the harvest cane green with mechanization generated social impacts at workers. In this way, the main objective of the research was to understand the social impacts, more specifically the unemployment and (re) insertion in the labour Market, of the workers with the end of manual sugarcane harvest in the Microregion of Ituiutaba.

The methodology included the qualitative approach, through semi-structured interviews with the president of the union of workers and representatives of the sugarcane agribusiness and with eighty former workers of the manual harvest in the region. The results showed that the great majority of the workers in manual cane harvest are migrants from the Northeastern states of Piauí and Alagoas. The agribusiness in the region prefer these workers because they lack local labor and because they have more physical resistance and they are more "submissive" to the imposed working conditions. The bankruptcy of sugarcane agribusiness in the Microrregion, the substituition of the manual sugarcane harvest by the mechanization contributed to the closing of hundreds of jobs, causing unemployment and worsening the living conditions of these workers.
\end{abstract}

Keywords: social impacts, sugarcane, precariousness in work
Volume I Issue 4 - 2017

\author{
Jussara dos Santos Rosendo,' Patrícia \\ Francisca de Matos $^{2}$ \\ 'Deaprtment of Geography, Federal University of Uberlândia, \\ Brazil \\ ${ }^{2}$ Department of Geography, Federal University of Goiás, Brazil
}

Correspondence: Jussara dos Santos Rosendo, Deaprtment of Geography, Federal University of Uberlândia, Brazil, Email jussara.rosendo@ufu.br

Received: July 20, 2017 | Published: October 30, 2017

\section{Introduction}

For almost two decades Brazil has become an important producer and consumer of biofuels as an energy alternative. The need to replace fossil fuels with clean fuels has given Brazilian ethanol an outstanding position. With the market promising, Brazil has been the scene of a growth of the cultivation of sugarcane monocultures to supply the sugarcane industry in the production of ethanol, sugar and energy. Data from $\mathrm{FAO}^{1}$ indicate that Brazil ranks first in sugarcane (ha) with more than 10 million hectares of production, followed by India ( 5 million hectares) and China (1,700 million hectares). Currently in Brazil, the main sugarcane producing region is the Southeast, which in 2015 produced about $55 \%$ of the national production, with the state of São Paulo being the largest producer, followed by Goiás and Minas Gerais, according to data from the Brazilian Institute of Geography and Statistics. ${ }^{2}$ The mesoregion of the Triângulo Mineiro and Alto Paranaíba, where the microregion of Ituiutaba is located (Figure 1), has become in the last decades a favorable territory for the growth of the sector in function of the following factors considered primordial and strategic: physical (climate, soil, and water resources), location, logistics, government incentives and environmental legislation with few restrictions (Figure 1).

The expansion of sugarcane production has restructured the agrarian space of all the municipalities of the microregion of Ituiutaba, changing the relations of production, replacing crops and concentrating land. Cane cultivation has been expanding in agriculture and livestock areas, situation that is visible in properties located within a 50 kilometer radius of the sugarcane agribusiness, which leads to a gradual decrease in diversified food production and culminates in the expansion of sugarcane monoculture. The devaluation of small agricultural activities and the lack of incentive to their continuity are determining factors for many small producers to yield to the ease of leasing their land. In Brazil, the traditional system of the manual harvesting of the cane with the previous burning (Figure $2 \mathrm{~A}$ ) is in substituition for the mechanized harvesting system without burning (Figure 2B). One of the reasons for this is the implementation of laws for gradual reduction of fires, being allowed only in areas with declivity above $12 \%$ (due to the limitation of the machinery in these areas). Several are the social impacts associated with the end of the manual cutting with the burning of the cane, the main one is the unemployment of workers who usually leave their states to migrate to the most productive regions of the country (Figure 2).

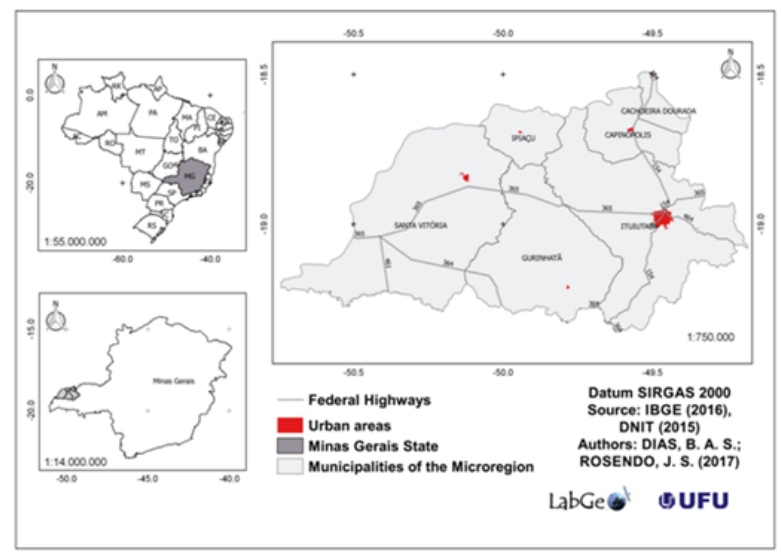

Figure I Localization of research area. 


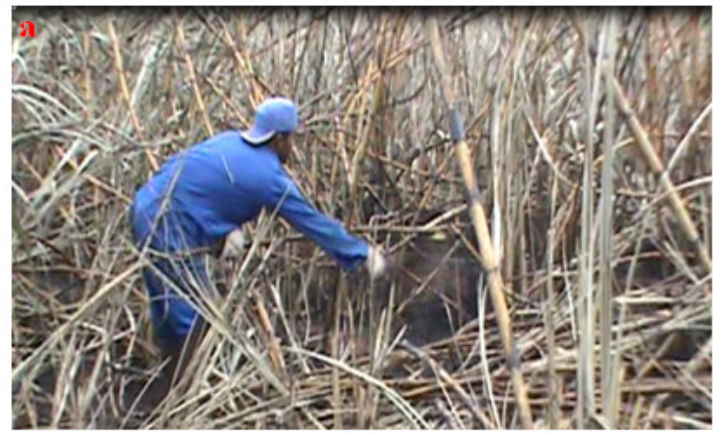

Figure 2 sugarcane manual harvest $x$ mechanization. "

The mechanization and the prohibition of burning have a positive side for the environment, to other side generate social and financial impacts for workers. The end of the manual harvest associated with the bankruptcy of two sugarcane agribusiness in the Microregion resulted in the unemployment of more than 1000 people (acoording to the President of the Union of workers). Without qualification, some of these workers continued to reside in the Microregion while another portion returned to their states. It is important to note that it was not up to the worker to decide whether or not to continue to manual harvest, because his work was being replaced by the mechanization without alternative compensation of these negative impacts was proposed. The main objective of the research was to understand the social impacts, more specifically the unemployment and (re) insertion in the labour Market, of the workers with the end of manual sugarcane harvest in the Microregion of Ituiutaba. The methodology included the qualitative approach, through semistructured interviews with the President of the Union of workers and eighty former workers in the region. The application of the forms with the workers was carried out in September and October of 2015 and at their option, they occur at their residences in the city of Ituiutaba, Capinópolis and Ipiaçu, at weekends and holidays, with schedules previously scheduled. The roterio, was composed of ten closed questions aiming to identify social data, such as origin, age, marital status, schooling, working time in the manual cane cut, and financial yield at the sugarcane harvest and currently. The five open questions sought to verify current working conditions, dissatisfaction with the process of mechanization of sugarcane, the main difficulties of manual cutting of sugarcane, among other issues.

The interview with the President of the Union of workers was held in April 2015, with the objectives: to understand the main difficulties faced by ex workers with thw end to the manual sugarcene harvest; to understand the help of the Union to former workers, and; the indication os workers to be interviewed in this research. Thus, the president of the union indicated five workers to be interviewed, so they indicated other workers until we reached a total of 80 people. In this way, the selection of the former workers considered: the longer working time in the manual sugarcane harvest and the appointment of the President of the Union and of the workers themselves. All workers interviewed are male (activity predominantly performed by men in the region).

\section{The sugarcane and precariousness in work}

The cultivation of sugarcane is associated with the economic history of Brazil. The planting of this monoculture was introduced in the period of colonization, constituting one of the main economic activities of the country. With the oil crisis in the 1970s, the government implemented public policies to expand sugarcane production with the goal of creating alternative energy sources, as opposed to dependence on oil. Proalcool was created, considered one

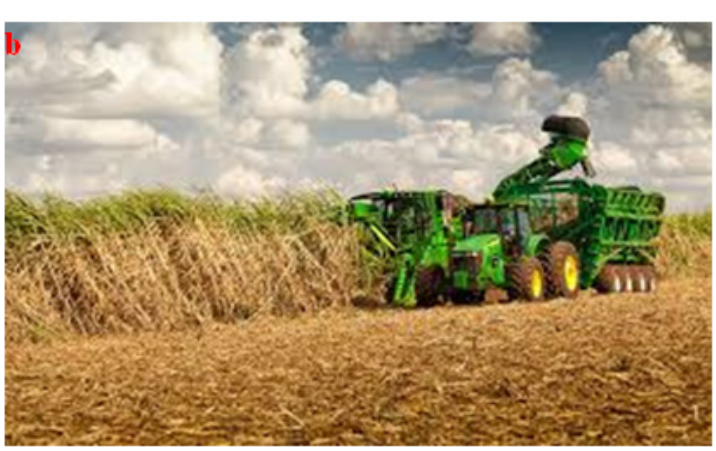

of the world's largest renewable energy programs, with the objective of stimulating the growth of Brazilian sugarcane plantations to supply domestic and foreign market demand. Since the year 2000, new incentives have been made possible by the government and private national and international initiative, enabling the expansion of sugarcane production in several regions of the country, due to the need to replace fossil fuels with clean fuels and by increasing the production of fuel- flexl vehicles. In Brazil, the main source of the energy matrix of biofuels is sugarcane, so the expansion of this crop has occurred in several Brazilian regions.

In the Ituiutaba microregion, since 2005, sugarcane has gradually increased production (Table 1), mainly in the municipalities of Santa Vitória, Ituiutaba and Capinópolis (Table 1). The increase in migrant labour in the Microregion was associated with the expansion of sugarcane plantations over the ten-year period (2003-2013), mainly in the Northeast region, of the states of Piauí and Alagoas. As a result of the lack of local labour, workers in these states are considered a "good choice" because they also have greater physical resistance and submission to the precarious working conditions imposed. The perversity and the precariousness of manual harvest are observed when analyzing the physical effort required in the activity, in addition to exposure to the sun, the movements are repetitive and the intense fiscal control that determines the division of the ranks occurs. Generally, the most productive workers are placed in proximity, which contributes to the competitiveness between them. In addition to the intense workload and physical effort, there is no adequate diet to supply the calories expended in the various activities of the harvesting process. Therefore, the ideal in the harvesting process would be teamwork with rotation of tasks so that the salary does not consider the tons cut during the day. This is a form of salary more advantageous to the capitalist since the intensity of labor does not depend on constant capital investments, but on the worker himself. It is a salary that reinforces the differences in skill, strength, energy, perseverance of the individual workers, causing differences in their incomes and the establishment of competition between them. This competition stimulates the increase of the intensity of the work and, consequently, of the productivity. ${ }^{3}$

As a form of payment, the sugarcane agribusiness use productivity, a sort of "trap" because it "obliges" the labour intensive to achieve better remuneration. Santos ${ }^{4}$ pointed out that his pace at work is therefore conditioned to what he has to pay, such as the rent of the house and the food he needs to regain his strength and recover for the day's work. Thus, it can be said that the worker always works at an amazing rate because his salary is insufficient to satisfy all his needs of social reproduction, whether the material necessities such as housing, clothing and food, or the spiritual necessities that involve Leisure, sociability and their training. 
Table I Planted area (hectares) and quantity produced (tons) of sugarcane in the municipalities of the Micturegion of Ituiutaba. ${ }^{2}$

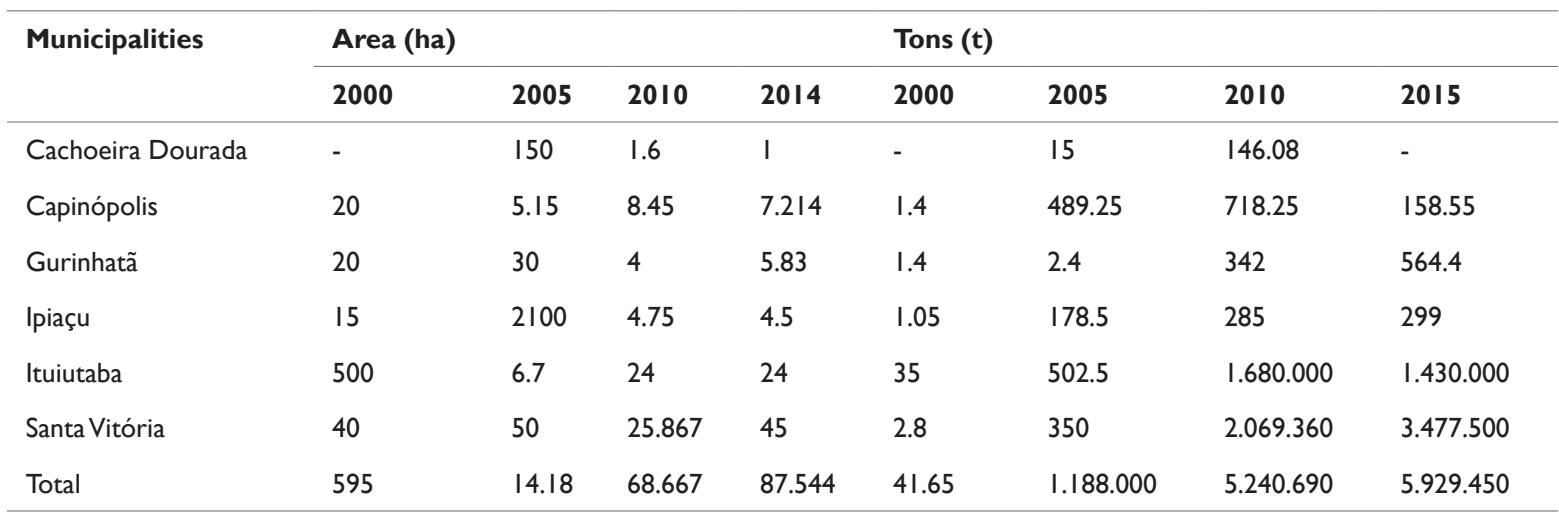

For Santos, ${ }^{4}$ the physical effort performed by the hand-cutter, added to the environment polluted with hydrocarbons and particulate matter resulting from the burning of the cane, causes the appearance of cardiovascular and respiratory diseases. Alves, ${ }^{5}$ in the work entitled "Why do sugarcane cutters die?" comments on the work routine of a sugarcane cutter, showing in detail the process to which it is subjected in this productive activity. The manual harvest sugarcane in Brazil is one of the activities that maintains analogy to slavery by the conditions of workers' overexploitation. Denunciations of slave labour in the sugar plantations are constantly reported by the media, or because of poor conditions or because of "debt bondage." In the flagrant situation occurred in 2014, in the city of Bauru (state of São Paulo), the employer kept the workers in private jail and deducted from the salary the products that he himself provided to the workers.

Capitalism has no social concern with Brazilian sugarcane workers, which leads to new guidelines for cost reduction and gains in profitability. The increase in exploitation over the worker is verified when one considers productivity in the 1980 s when a worker needed to cut $8-10$ tons of cane per day, while in 2010 that figure increased to around 15 tons per day. With the process of mechanization (one machine does the work of about 100 men) hundreds of people became unemployed. As in other regions of the country, workers did not have access to training for other compensatory activities and/or policies that could (re) place them in the labour market.

\section{Social impacts to the end of the sugarcane harvest in the microrregion of ituiutaba (minas gerais, brazil)}

The Ituiutaba Microregion has for almost two decades been a prominent position in the production of sugarcane in the state of Minas Gerais, due to the establishment of sugar and alcohol mills. Currently, there are two agribusiness of sugarcane, British Petroleum (BP), installed in the municipality of Ituiutaba and Santa Vitória Sugar and Alcohol (SVAA) in Santa Vitória. In 2013, two sugarcane agribusiness that still had manual harvesting of sugarcane in the micro-region, decreed bankruptcy, generating unemployment for hundreds of workers, including sugar cane cutters. The bankruptcy of these plants and the process of mechanization due to the fire ban (also because it was more profitable) contributed to the extinction of jobs of the sugar cane cutter in the region. The unemployment was considered to be the main social impact in the lives of these workers, so that research focused on the effort to investigate how these people came to survive after losing their jobs, thus other social impacts such as violence, social vulnerability, poverty, among others, were not evaluated.
For manual harvesting, workers in the Northeast, mainly the states of Piauí (PI) and Alagoas (AL), were preferred by agribusiness, not only because local labor was lacking, but because they are had more physical resistance and greater "submission" conditions imposed by the mills. At the time of the harvest, there were about a thousand workers in the cane cut. At the end of the harvest, many migrant workers stayed in Ituiutaba or other cities of the Microregion while others returned to their cities of origin. Of the former workers surveyed, the majority $(60 \%)$ have been in the Ituiutaba Microregion for more than five years, $30 \%$ have been in the region for less than five years and the remaining $10 \%$ are from the Microregion.

The Northeastern region of Brazil is marked by severe droughts that punish rural workers, lack of employment opportunities in the countryside and in the city, which makes migration to other regions of the country an opportunity for better living. Galiano et al. ${ }^{6}$ affirm that migration is not an option but rather a compulsory one in these cases, the authors also point out that when researching young migrant workers in the manual sugarcane harvest, they identified that the main factors that influence the decision to migrate is the absence of jobs and prospects in places of origin, the influence of friends / family and the possibility of financial help to the family.

With the end of manual harvest, a portion of these workers returned to their places of origin while hundreds of people settled in the region, seeking to enter the formal and informal labour market. Of the former cane workers interviewed, the majority $(60 \%)$ reside in the Ituiutaba Microregion for more than five years, the remaining (40\%) for less than five years. About the experience in manual sugarcane harvest, $24 \%$ reported a period of 6 to 10 year; $60 \%$ between 1 and 5 years and $16 \%$ more 10 years. Regarding the age of the workers, $40 \%$ are between 40 and 50 years and $48 \%$, between 20 and 40 years, proving, that this activity requires younger peopleos, due to the expropriation of physical force. Although young, they present health problems caused by the precariousness of manual harvest. Sugarcane cutters present pathological conditions composed of diseases such as dyspnea, lumbar and thoracic pain, cramps, spinal cord involvement, dehydration, blood pressure fluctuations, gastrointestinal problems, respiratory infections, dermatitis, conjunctivitis, poisoning from poisonous animals and pesticides, accidents at work and on the road, among others.?

The low level of schooling of these workers was verified, $64 \%$ had primary education, $8 \%$ had secondary education and $28 \%$ were illiterate. This fact collabore to continue working precariously, subjecting themselves to the exploitation of their workforce and low 
remuneration. Without school education, these former workers find it difficult to enter the labor market, especially with a formal contract, work rights and coverage in the event of unemployment and illness. Look at the testimony of former workers:

i. If I had at least one good reading, I could get the driver's license to get a tractor or truck job, but my whole life was dealing with manual labor. The dream is to have a signed wallet, to live in peace (Interviewee A).

ii. I could not finish my studies, I could not do any technical course, because I have always worked hard and did not have mood to go to school, today I see how it needs to be, because all jobs with formal contract require Basic education. For agribusiness we are disposable (interviewed B).

After the extinction of manual harvest, a significant proportion of this peoples works as a auxiliar construction worker $(36 \%)$, gardeners $(12 \%)$, general services $(12 \%)$, agricultural auxiliaries $(8 \%)$ and/or others activities. It has been reported that these services are sporadic and remunerated per day of work, which does not guarantee the minimum financial conditions for maintaining daily necessities. Driver positions and trade-related activities are responsible for absorbing $20 \%$ of the workforce. A total of $12 \%$ of the respondents reported unemployment and the receipt of aid (foods).

This last fact was reinforced in the interview with the President of the Union of the workers, who reported that with the end of the manual sugarcane harvest in the region, many workers seek daily the Union to request help to food, medicines and indications of jobs. Nunes, Silva and Cordeiro ${ }^{8}$ also identified that the former cane cutters that were and continue to be replaced by the machines occupy other productive sectors, such as civil construction, in which the hardship, dangerousness and unhealthiness of work do not leave anything to be desired for the cutting of sugarcane. These data are justified because of the low level of education, according to the reports of interviewees $\mathrm{A}$ and $\mathrm{B}$.

Regarding salaries, $56 \%$ reported income between 1 and 2 minimum wages (lower than they received in sugarcane harvest), $36 \%$ up to 3 minimum wages, $4 \%$ up to 1 minimum wage paid in Brazil (R\$ 840.00 or US\$282.00) and 8\% did not know how to respond. In manual harvesting of sugarcane, wages depend on the productivity of each worker, so the higher the tons harvested during the day, the higher the wage at the end of the month. This situation leads the workers to almost exhaustion, because to gain a little more, they are subject to high working hours. Galiano et al. ${ }^{6}$ reported that the worker requires, besides the skill to handle the sickle, a lot of physical strength, willingness to face the hardships of an unknown region, with climatic contrasts and the precarious living conditions. As a consequence of lack opportunities, of the total, $64 \%$ answered that they would work again in manual harvesting and $36 \%$ said that they were not due to physical exhaustion and age, reinforcing to the that to reach a little higher wages requires greater physical strength. It is important to point out, once again, that the worker's wage is linked to the amount of sugarcane cut per day, constituting a perverse form of remuneration, since it is the labor force - productivity - that will guarantee its gain. The payments systems in the manual sugarcane harvest "are important weapons, made available by capital, which guarantee at the same time the maintenance of the extraction of overwork, as well as the control of the work process and the overexploitation of labor, which reaches the streaks of semi-slavery". ${ }^{\circ}$
Workers leave their places of origin and leave their homes and families hoping to achieve better living conditions than those to which they are subjected. However, the reality of manual sugarcane harvest is not the same as that of the imaginary. When they arrive at the places where they will live during the harvest period, they are placed in accommodation with other workers. It is important to note that, in addition to the precarious and strenuous working conditions in the sugarcane plantations, the workers' housing is far from being suitable places to live, since they are usually small to accommodate the number of workers and the absence of ventilation, which generates discomfort mainly in the hottest months of the year (the maximum average temperature in Ituiutaba in October has already reached $35^{\circ} \mathrm{C} .{ }^{10}$ With regard to the Individual Protection Equipment (PPE) required by Brazilian legislation, workers receive long-sleeved $\mathrm{T}$ shirts, hats, boots with shin guards and gloves, to protect themselves from the sun and venomous animals. However, they hardly receive protection masks against the soot caused by the burning of the cane, which causes breathing problems.

The work begins early in the morning (6:00 AM and can go up to 4:00 PM), they are exposed to high incidence of ultraviolet radiation, not receiving sunscreen to protect themselves. By the foregoing, although aware of the precariousness to which they are subjected in the manual harvest of sugarcane, many workers continue in this activity. Of the interviewees, $32 \%$ consider that manual harvest is a very tiring job; $40 \%$ believe that low pay is one of the most negative aspects and $28 \%$ emphasize exposure to the sun. Lastly, sugar cane cutters who have been used for decades as a precarious labor force to keep the activity expanding, have been replaced by machines harvesters, promoting the quantitative elimination of these jobs and the unemployment of thousands of workers. Once again, one experiences the conjuncture of a "new" stage of conservative and perverse modernization, without public policies that diminish social impacts.

\section{Consideration}

The process of mechanization of the sugarcane harvest in Brazil began in the 1990s and gained momentum in the last ten years, due to the prohibition of sugarcane burning and also the economic advantages for the sugarcane industry. In the Ituiutaba Microregion, this process occurred in 2013, promoting the unemployment of hundreds of workers, since they were not reallocated to other activities in the plants. In this context, the data revealed that most of the workers interviewed did not stop working in a precarious way, without a formal contract, in the informality and with a large wage loss. According to the profile of the interviewees, only $8 \%$ have high school and this makes it difficult to obtain other jobs. In addition, they did not have access to preparation courses for other activities, which represents a great social impact of the mechanization process. It is important to consider that the mechanization process does not occur only in the Ituiutaba Microregion, but in all the sugarcane producing regions in Brazil that will fit the environmental protocol, in order to extinguish the fires until 2018 and, consequently, the end of manual sugarcane harvest. Not only at a local, regional and national level, there is still time to plan the fate of cane-cutters, with partnerships between local, state and power plants, educational institutions, to develop professional training projects to take on new jobs that are not precarious as in the cane fields and the realization of the agrarian reform, contemplating also these workers. 


\section{Acknowlegments}

To The Fundação de Amparo à Pesquisa do Estado de Minas Gerais (FAPEMIG) and the Conselho Nacional de Desenvolvimento Científico e Tecnológico (CNPq) to supporting this research.

\section{Confilict of interest}

The author declares no conflict of interest.

\section{References}

1. FAO. Food and Agriculture Organization of the United Nations. Brazil; 2014.

2. Matos PF. Brazilian Institute of Geography and Statistics. Municipal Production of Minas Gerais. Brazil; 2015.

3. Silva MAM. Wanderers of the end of the century. Brazil: Editora Foundation of UNESP; 1999.

4. Santos AP. The satanic mill of sugarcane agribusiness in Brazil: dependence and superexploration of work in the region of Ribeirão. Thesis (Doctorate in Sociology) - Graduate Program in Sociology, Institute of Philosophy and Human Sciences, Campinas, Brazil; 2013.
5. Alves G. Structural capital crisis, immaterial work and models of competence: new dialectics. In: Alves G, et al. editors. Work and education: contradictions of global capitalism. Brazil: Praxis; 2006.

6. Galiano AM, Vetorassi A, Navarro VL. Labor, health, and migration in Sugarcane plantations in the region of Ribeirão Preto, São Paulo State, Brazil: what do Young workers perceive and feel? Revista Brasileira de Saúde Ocupacional, São Paulo. 2012;37(125):51-64.

7. Scopinho RA. Vigiando a vigilância: saúde e segurança no trabalho em tempos de qualidade total. Brazil: Annablume, FAPESP; 2003.

8. Nunes DM, Silva MS, Cordeiro RLM. Work and risk experience among Northeastern migrant works in sugarcane plantations in the state of São Paulo, Brazil. Saúde e Sociedade. 2016;5(4):1122-1135.

9. Thomaz Junior AA. Behind the sugarcane plantations, the sugarcane knots: the capital $x$ labor relation and the workers' union movement in the São Paulo sugar cane industry. Brazil: Annablume, FAPESP; 2002.

10. PC Mendes, Queiroz AT. Caracterização Climática do município de Ituiutaba-MG. In: Portuguez A, et al. editors. Geografia do Brasil Central-Enfoques teóricos e particularidades regionais. Brazil: Editora Assis; 2011.

11. Silva LCS. Photo of sugarcane harvest. Brazil: Google Images; 2017. 